\title{
Further Urban Development from the Beginning of the Century to the End of the 30s
}

\author{
Eftiola Thanas
}

Work in DRTK Korce

\begin{abstract}
The years '20 - '30 of the last century brought great economic development for our country, and in particular for the city of Korca. In this period, urban planning and especially its implementation received great attention. At this time Korca was thinking of changing and improving its existing urban structure. The citizens and intellectuals of Korça, through numerous discussions that took place in the press of the time, provided their solutions to the main urban problems, such as the city river, electrification, roads and boulevards, forestation, etc. The introduction of new ideas for solving the urban problems that the city faced in that period turned Korca into a reference point for their implementation. Making it the center and reference point for the urban developments that he was conceiving and using in that period. This was the Korca of the '20s and '30s, the city of ideas, development, and social, economic, architectural, and urban change.
\end{abstract}

Keywords: urban development, boulevard, public space, "Korca River", electrification, forestation

\section{Introduction}

The birth and development of capitalist relations in our country in addition to reflexes on the typology and character of the civil residence find the expression and the urbanism of this period. But it should be noted that while in the apartment the changes are quick, and with a relatively broad reach, in terms of urbanism, the new arrivals are limited, so with a small extension even in the city of Korca. The medieval, urbanism in which both residential and economic areas were conceived was based on a lack of planning. It was characterized by improvised solutions, with a road net without, a clear criterion. Without denying particularly striking achievements, in urban areas or quarters on sloping terrain, medieval urbanism represented outstanding shortcomings associated with that developmental stage of Albanian society conditioned by the feudal order. The beginning of the emergence of capitalist relations was delayed, or, rather limited, in urban 
planning, because in many cities old urban planning schemes had long been consolidated, while new constructions did not constitute a huge volume (Riza, 1980).

Just as in flat and urban planning, just in Korca, we are meeting for the first time in our country planning implementation in the construction of residential quarters. This phenomenon appears in a relatively early period even for the Balkans, having beginnings around the mid- $19^{\text {th }}$ century (Ibid. 2).

The new part of the city was built according to the same urban plan, as well as the new quarters of the previous period, and received the same denominations. The advantage of applying the orthogonal system to the conditions of Korca was clearly shown because the expansion of the city into free lands was not conditioned by the existing construction or existing urban structures. The features of this system and the ease of its implementation created good opportunities for the continuous growth of the city. But this system was implemented in Korca in full compliance with economic development and in close connection with the conditions of the city's terrain and climate.

The development of the orthogonal urban system is known in the period of ancient Greece and Rome. Thus, in ancient Greece, this type of system was born and developed, this type of town "for strigas", where the urban criteria were still lacking and the type of dwelling, paved the way for the implementation of the hypodamic system in the classical period. "... the city plan within the walls was divided into a quadrilateral system about $50 \times 90 \mathrm{~m}$ from a road network that interrupted at right angles. This is also the main feature of what is called the new style and is related to the Hipodam architect from Mileti. The main roads are 9-11 $m$ wide and follow the south-north facing or top-down slope of the hill" (Ceka, Korkuti, 1998).

While Roman urbanism was formed in the nineteenth century. 2nd BC under strong Etruscan-Greek influence. The Etruscan tradition of building cities relied on the organization of space according to the orthogonal system, with roads and sewers, with the distinction of the social area from the inhabited area, with the supply of the drinking water to the cities, etc. from this tradition, the Romans adopted the strict rules in the creation of the city including its limitation within a plum-iron groove (pomerium), the initial axles assignment of the decumanus (east-west) axes and the cardo (north-south) (Ibid. 191).

\section{Roads and Boulevard}

"The Korca roads are narrow but peaceful and constructed with stones.

Today, two great and righteous streets are Korca. One that called Saint George, with goes to the Albanian School of Apprentices and enters the market, the other, which comes from the north side of the city from which the passengers from Bitola 
arrive from Thessaloniki, which is divided in two on the shore of the St. Ilia, on track goes into the market,

the other one to Varosh of Above. In addition, two others leave the plot of Dredha and head towards the south, which is in Permet and Ioannina,

the best of all these ways is that of Saint George, which was quickly built and it is located on a boulevard, and is planted on both sides with shrubs" (Ziko, 2012)

The features of this system and the ease of its implementation created good opportunities for the continuous growth of the city. But this system was implemented in Korca, in full compliance with economic development, and in close connection with the conditions of the city's terrain and climate. New neighborhoods on both sides of the main commercial arteries with an important weight in the city's economic life. These arteries become the basis of the urban development, from where the road network develops (Thomo, 1987/1).

So this urban system created and proven that in the curly periods become a reason to apply even in our city which in some cases also preceded other countries for the implementation of this urban system in the development and construction of the city. So we take the case of our only testimony to the existence of a plan for our city in, 1910, which speaks specifically for its construction and organization, such as the case of road network organization where $8 \mathrm{~m}$ wide roads, are spoken which would replace the old road network and be replaced with new ones that would give a new impact to the city and new constructions that would be made. But the Korca citizens opposed this plan not because it seemed improper or inaccurate, but as it is distinguished by the scripture "... why would we need 8 meters wide landed in the river and in any of which they are barely long 20 meters spot? Then these gays serve 2-3 houses and not the entire city with which there is nowhere to go and there is no way to go out, that there is no bridge for the river as these close are today for today. It will tell us the new card reader that since we are preparing the moon in the river, these roads should be expanded and opened to adorn the city plot. We would be right if we had the hope that this look would be confirmed. But because our trial river has led us to believe that we should not have much confidence that it has broken us many times, so we are afraid and we must have a failure that we are preparing with our hand narrowing his way and expanding the city's roads and the houses behind the river without a benefit" ("Map of our city", 1910).

Thus we recognize that city plans, even though in their beginnings (with the only evidence we have) confirm and show that the advances were presented in this plan by changing city planning, were difficult to implement in the field for the very fact of the presence of the city river which as we will see below will create many problems for the city but also as we have mentioned for the bazaar. So the main part of the regulatory plans and why they are approved have been introduced from the outset as a regulator of the road system and that existing road system. 
So by the testimony and widespread activity of our city hall we see that it has been taken at all times by the regulation or even the disturbance of the streets of the city and in the article of 15 October 1929, we see that the article speaks of how they are managed and kept the streets, where this fact is raised in public opinion even in cases when the city hall does not make many moves to fix these paths. Thus, in a notice of "discontinuation" on 1 December 1930 in the "Korca Newspaper" we notice that the announcement made by the City Hall speaks of the construction of a road and the opening of the drainage channels of this road ie if we judge this article we can say that the activity of the Municipality in road-repair work was good and we often see such items where the municipality builds or regulates city streets and drainage channels of these roads.

Thus, if we see the announcement dated 8 November 1930 of the municipality in the "Korca Newspaper" we recognize that it has failed to repair the channels of these roads: 1. Krastafillak Street in New Neighborhood; 2. Vasil Tromara in the New Neighborhood; 3. the Tosk Street in the Manco neighborhood; 4. Dunavece Street in the Kulla e Hirit district. Also constructed in the way of the road Tushi Krastafillak in New Neighborhood. So the municipality in this period even though it had not yet well-developed the city plan took measures to regulate and improve urban planning of the city.

So there are also cases where the City Hall is accused of not functioning in its structure for the maintenance of city streets as is the case when it says "... with all that we have said so many times, we are still repeating that the public roads of the prefecture they are in disarray. It's about two years since the competent offices show no animation for the streets, so with the coming of the winter the journey will be very hard and somehow impossible and impossible" ("Work for the roads, 1929).

So, there are times when the respective institutions are sometimes praised and sometimes judged by the public for their work whatever they do. This is good for the Albanian society of that society was developed and managed to express all that it thought in the press of the time.

If we browse the memory of, the citizens of Korca we find something special about the streets and the boulevards of the city; to draw attention especially to something that connects them more to these streets and especially to the boulevards; what is now part of the city's cultural heritage and conscience; famous Korca walks around these boulevards. Although they look a bit different from each other if we talk about the streets we can not fail to mention this tradition of Korca. These boulevards have been not only a transit artery but also a place for strolling citizens, Nikollaq Zoi, in his memorial book for Korca, proves that this beautiful tradition of the citizen of Korça, this traditional walk started for the first time in boulevard "St. George in 1906 ... in the evening, the boulevard of Korca, from Thimaq Cale's house to the middle of the market, filled with strollers. 
This walk in the thirties was moved to the "Republic" boulevard traditionally continued late (Ziko, 2012).

With the implementation of the orthogonal system even during the further growth of the city found a quick and satisfying solution to the housing problem. Also, the measures taken to sanitize the city by building sewerage, laying roads, etc., improved the urban structure. But yet to create a complete urban system, supplemented with other formative elements, there were still shortcomings and a lot of work to do (Thomo, 1987/1).

This walk on this boulevard was not just a common lap, that there was not just a stroll to get drunk with the smell of flowering acacia trees that enveloped the boulevard in these years, or the yew of the rose gardens. The boulevard was the fashion school of clothing, educated and cultured behavior, respect, and human ethics emancipated love, in a word, the scene of what is called the Korca tradition in the history of the culture of those years that made it Korca, is the most cultured and modern city in the country (Ziko, 2012).

The peculiarity of these people is not only their cladding but also the straight lines through which they stretch, plummeting over each other at their intersection. The eye is delighted and delighted to see from above the hills the blocks of the "mëhallave" and houses parcels as the symmetrical slices of giant baklava. They are concrete evidence of the modern, cultured design of the town's planimetry, designed with the mind and taste of the eye and the artistic hand of Korca citizens in years. This plan has given the city and its life the breathing of free movement and cozy communication. Our forebears have been people with an advanced vision for the time, who have chosen to choose the most advanced not only in the orientalization of the city's economic development but also in its architecture and planimetric, we should be proud of them as it should be careful and conscientious to preserve this urban tradition and to further develop it, always retaining its peculiar feature (Ibid. 49)

\section{Adding Public Space}

In this part of urban development and planning of the city, we can mention the initiative not only civil but also of the respective institutions for the well organized public and administrative and cultural-educational spaces. Especially at the end of the 1920s and throughout the 30s of the last century the city and the stateapproved plans devoted special importance and gave it the right importance. We can consider the case of the creation of two flowerpots in the city of Korca; the construction of the Municipality and the Prefecture, the National Bank; The City Library, the National and French Liceu; the "Mazhestik", the "St. Thanas" church, the Cathedral Church "Life Source" etc.

We take the first occasion of the construction of the "Themistokli Germenji" garden, located in the boulevard "Republic" in the New Neighborhood of the city. 
Thus, in an article in the city newspaper of 1928, we read: "On the occasion of the coming of His Excellency to the President of the Republic in Korca, kindergarten "Themistokli Germenji" will be adorned with railing, park bench, etc". So we recognize that this kindergarten is a space that functions as a public space and would later also embrace the meaning of public and cultural-educational space with the place where the bust was named and the City Library. So we recognize that the Municipality was interested in organizing and adding these public "gardens" in the city.

While in the case of construction and addition of public spaces, we have the opportunity to create such cultural and educational spaces as in the case of the establishment of the City Library which was not a construction of the Municipality but was a construction initiated by a philanthropist of Korca Thoma Turtulli, "Thant the Korca boyhood be cultured".

So we see that on May 28, 1928, in that "Korca Newspaper", we read: "the building of our City Library which as it is said, was raised at the expense of Mr. Thoma Turtulli, within a mound is finished altogether". So it turns out that the efforts of the Korca citizenship and philanthropy of the city have started in 1928 and have been expelled in November 1930 on the occasion of declaring the independence of the country. As it emerges from the debates reflected in the press of the time, we see that even though the library building was finished and was handed over by the Municipality it continued to open and not function for the purpose it was built, see the article titled "When will the Library's Tops?" (Gazeta e Korçës, 1929). Where not only the newspaper executives but also the indignation of the citizen of Korca for not opening the Library is great as they begin to cast doubt on why the Municipality is not opening it because it has taken over the building for a long time. And we end up with the inauguration of the City Library on November 28, 1930 (Gazeta e Korçës, 1930). We have other public buildings of a cultural and educational character such as the French Lyceum, the National (by Thoma Turtulli), the Technical School, as well as the contribution of Korca citizenship of two first works of art in the field of sculpture in the city of "National Warrior" and the patriot "Themistokli Germenji".

Of particular importance and clearly defined in the regulatory plan of 1930 is the City Hall and the later the City Prefecture building. Both of those public spaces undertaken by the City Hall itself, as it is the case of the City Hall which was designed as part of the city plan and also as part of the changes set out in this plan, nowadays there is no city plan how this plan is not even in the AQTN, but I have come across a fascicle and some plans that talk about this plan and especially about the arrangements made in the 1930 plan. Also, these spaces are designed or not by the respective institutions comprehensively make interventions and changes in city planning. 
But the urban changes, the city of Korca did not only stay in these simple urban planning points, but it reached the point of interfering with city planning by attempting to gratify the "Maliq Lake" and especially what continued to be "the plague" for the city on till the ' 60 of the last century, the city river. In both of these cases, we have intervened in the City Hall with plans and with proper arrangements to change them, although in both cases we have a failure because we could not change it and improve or better still to change it by interfering its urban planning.

\section{Plan for the "Korca River"}

He is called the city river, but in fact, it was a mountainous Moravian torrent, like all the rivers of the mountains, gathering rivers, spinning rains, or snow when it starts melting in the spring ... the three great wooden bridges, two small iron castiron bridges, and a stone, a pole that had been laid between its two banks. His bed was different and disordered, ten, twelve, and more meters wide. In the café of Panda was deep and between a two-lined shore, there was a hanging wooden bridge without side walls shaking when walking hurriedly. ... below, there was a concrete bridge near Xhoxhi mill, after which there was a deep pit, and it become a great pond where the cross was cast on the Day of the Blessed Water. Below, on the massive black rock in the middle of the river bed, Pilos were milled. A hundred meters below, now passing the road through Fan Noli Boulevard, was the first large wooden bridge in today's Polyclinic was the second bridge connecting the other shore, where the little Mosque was located; the third wooden bridge bound the two banks along the city Hall, about one hundred meters further, before the river entered the cube, the stone pavement on which Thoma Rroton's shop was located was another narrow bridge of concrete and that of the stone, to take you to shop, where there were tend of shops. The two abovementioned mills were the only two drawbacks for the city built on the bed of this river not counting the "benefits" that had the banks of the river, which used its bed as a garbage bin that cleansed it not, only, the Municipality but, also the river when hailing in Morava (Ziko, 2012).

The Morava river, which has always been had for the city all the time, due to the fact that its frequent outflow floods have flooded homes that were located along with it, and often caused damage to the area and the heart of the city in shopping. So the river at all times has been "still", from the searches made in Korca Gazette we see the efforts of the citizens and the Municipality to change this but without any result. Two articles talk about "river regulation" prepared by ing. J. Adam, where he inter alia writes: "the day before yesterday, on panic 28 August, I apply the seats of our city, from the great rainfall that hit the Morava mountains floods were filled and water with extraordinary attacks crashed in the Korca river, ruining and grabbing everything ahead. The market found great damage, a disadvantage 
that could not have happened if our Municipality had given river regulation the importance it deserved.

What is the river of Korca?

Our Korca river is a dry river, without water, and in winter with little water, its resources are very close and its water descends from the hollow mountains. Because the mountains are without a forest and the slope is large and close to the rainwater without finding a stop immediately in the city. And when he is many, he does what he did yesterday. What needs to be done to regulate it. The best and safest way to save ourselves from the wild water of this river is to afforest the mountains of Mborje and become cascades (dry walls) in the moorland at the length of time to wait for the power of the river waters and stop the stones that it brings. But since this measure is not so easy and free and without the government's support it can not be applied, another leg is found:

Take the whole river in Drenica

A few years ago, our Municipality was serious about this job and greed with a specialist who had made a plethora and a score for this, something that was never heard. I do not know why this platform was not implemented: they want to say that there is a lot of money that the Municipality does not have. Indeed, the Municipality does not have enough income to do so a great job, but it is enough to do this work for several years, allocating part of its budget for a while. ...before any other work has to be taken into account how we will be saved from the wild water of this river and the start from the beauties. This is my admission Ing. J., Adam" (Ziko, 2012).

So by the article of one of the pioneers of Corsair engineers, we got answer to all the questions that could have at that time how best to solve the river problem and how with the timing interventions and advances of time could be saved from this plague great for the city.

But the final "engineering" solution comes a little later, which was implemented many years later. "Rivers Regulation", the article speaks of how to be saved and how can it be achieved: "... taking into account such a danger, and they were about to beautify the city, four years ago. Turn the river off the city by the side of a huge canal and charge a foreign engineer to prepare the plan....Mr. Hil Mosi, with a letter sent to the Municipality, says that two types of actions are to be considered: a) river restraints, over the Mborje mills down the Panda café Osmalliu with the side of "gabionavet", so that as the speed of water is strengthened, so the great rocks that the river brings is stopped. b) the river channel, according to the project of the engineer Vllamos which starts since the first mill of the city is streamed to Drenica. Mr. Prefekt adds that this work, which the municipality has until now appeared to be a colossal work that will capitalize on math, could do so easily with the entry into force of the law of the communes, after which every male is obliged to work six days a year. Thus, after an approximate account, for the opening of a canal at a length of 
900 meters, with a width of 10 meters and a depth of 2,50 meters will be caught about 15000 workers, who working on overage 150 people per day, the works the can do it within 100 days. ...Mr. Prefekt proposal to channel to the river with the forced laborers seems to us to be the most liked and easiest way. Therefore, the Municipality has to accept without bargaining and start working as soon as possible. Any delay of the Municipality on this issue can be considered as a major crime for the city for many reasons" ("River of the city", 1924).

So this wound from Korca and intellectuals gave him a solution, and with the later article that we come across in the press of the time this wound continues to be open and bring damage to the city and it continues that citizens complain about this work without making. Although in the area of urban planning, and design it was a breakthrough, the fact that this plan existed, even though today is not located, was an achievement and a great urban asset for the time that has come to our day. It is a precious heritage and presents the history of the urban development of the city, raising this aspect of the city to that level with other Balkan and European cities.

\section{Electrification, forestation and drying of Lake Maliqi}

But other urban developments can be mentioned: the electrification of the city, the crying of the Maliqi lake, and the forestation of the hills of the city. As for the electrification of the city, we can say that this has started since 1925 in August September, so it appears in the delivery of the city newspaper of that period which reads: "...with joy we hear that is signed the contract between the Municipality and Ilektric society for the brightening of our city" ("Electrification of the city", 1925).

Also in the following article, we find the following: "As after the Administrative Adjudication decision of 18 August, the Ordinary Shares of the General Anonymous General Corporation of Ilektric will take place from 1 to 30 September 1925. The Shared Value is 100 francs ar suskkripsion: Slusripsionet on the Ordinary Share are made in the Company's Office located on the second floor of the Magazines of vell. I, sleep ate 9-12 p.d and then 4-6: 30 after m.d" (Ibid. 2). So from this, we can see that until this period Korca was advancing in the urban development of the time and they had reached such a point as to make such discussions in public or even in queries that sought and made known about the continuity of these works, in addition to the city.

As for the other urban development's of the period in the city, we have also dried up Maliqi Lake as the river of the city was a wound that had to be healed, so we took the chance to dry the lake started in August 1924 with a press release the time when the creation and launch of measurements and all the preliminary preparations to see the possibilities of drying and returning of this space to agricultural land becomes known, at the beginning we have Ing. K. Vllamo ("River of the city", 1924), who "... His Mr. to two weeks ends the measurements of the lake. Then after the convention, we have done, we will return to Thessaloniki with the 
technical tools to work the lake map together with its districts and the plan that will contain all the details of the work". On September 2, 1929, we have another announcement that highlights another initiative and other calculations regarding the situation in question and gives accurate conclusions on whether something can be achieved or not. "In charge of the Technical Director of the Anonymous Company "Maliq" I studied all the planners and reports, made by the engineers who have been dealing with this issue and made surveys different surveys as I concluded that the current work done by the company is beneficial and that the drying of the lake not only continues regularly but also in the future is technically secured. So I found out that after the works so far the lake water surface has descended 1 meter and 60 centimeters, ie: to half the old depth measured all in that month", Ing. Bartoli Enrik. But besides the inspections of this project of this new engineering that is loaded by the society itself, the solution of many other problems, such as the river and other streams of the Korca area, makes it possible to join all this in a single stream, not only the drying of the lake but also the removal of the city's river water. And the latest initiative of Korca's citizenship to change the urban planning of the city and what is called in the language of urbanists "skyline" was the forestation of the surrounding hills of the city. This initiative, initially acquired by the Korca citizenship and later embraced by the educational bodies of the time overwhelmingly "on the day of trees" ("On the day of trees", 1934), has managed to change and make the city a good one. We read in the press of the time various complaints from various article writers regarding the summertime and the great sun that falls in the cafés raised in these parts of the city. Even the reasoning came to say that most of the population can not go to a picnic in these areas because of the lack of greenery and they can not stand for the fact of the great sun. The first initiative for the forestation of the "hillock of Shendellise" was, received by the priest serving in this church, Stavre Kanxheri, who had managed to plant 2-3000 roots of trees, but after a while, the priest himself began to complain and seek help the organs for the fact that they had started to spend their income and that they could not continue doing this great work for the city.

So we see that in this period different urban developments are numerous and all have influenced and left as we have said above a legacy of value for our city.

\section{References}

[1] Ceka, N. Korkuti, M. (1998). Arkeologjia. Tiranë

[2] Electrification of the city, (1925 August 18). Gazeta e Korçës, p. 2

[3] Inauguration of the City Library (1930, November 28) Gazeta e Korçës, p. 2

[4] Map of our city, (1910, May 20).Gazeta e Korçës, p. 2

[5] On the day of trees (1934 December 12), Gazeta e Korçës, p. 1 
[6] River of the city, (1924 August 9) Gazeta e Korçës,: p. 3

[7] Rivers Regulation, (1929 September 8) Gazeta e Korçës, p. 2

[8] Riza, E. (1980) Banesa qytetare shqipëtare gjatë gjysmës së dytë të shek. 19 deri rreth çerekut të parë të shek. 20, Monumentet 20. Tiranë, 30-44

[9] Thomo, P. (1987) Qyteti i Korçës dhe arkitektura popullore shqipëtare gjatë gjysmës së dytë të shek. 19 dhe fillim të shek. 20, Kultura popullore 1. Tiranë, 109-124

[10] Thomo, P. (1987) Tipare urbanistike të qytetit të Korçës në vitet 19121944, Monumentet 1; Tiranë, 109-131

[11] Thomo, P. (1987) Tipare urbanistike të qytetit të Korçës në vitet 19121944, Monumentet 1. Tiranë, 109-131

[12] Thomo, P. (2012). Korca Urbanistika dhe Arkitektura. Tirane, Albania: Morava

[13] When will the Library's Tops?, (1929, November 19) Gazeta e Korçës, p. 1

[14] Work for the roads, (1929, August 15) Gazeta e Korçës, p. 2

[15] Ziko, V(2012). Korça (qyteti dhe kujtime). Korçë: Kotti 